\title{
Nonlinear models for soil moisture sensor calibration in tropical mountainous soils
}

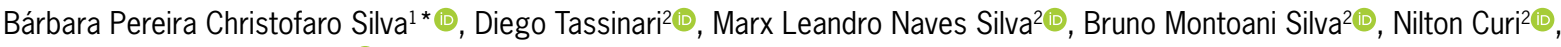 \\ Humberto Ribeiro da Rocha ${ }^{3}$
}

\begin{abstract}
${ }^{1}$ Instituto Federal de Educação, Ciência e Tecnologia do Pará, Av. Prefeito Nelson Souza - 68250-000 - Óbidos, PA - Brasil.

2Universidade Federal de Lavras - Depto. de Ciência do Solo, Av. Dr. Sylvio Menicucci, 1001 - 37200-900 - Lavras, MG - Brasil.

3Universidade de São Paulo/IAG - Depto. de Ciências Atmosféricas, R. do Matão, 1226 - 05508-090 - São Paulo, SP - Brasil.

*Corresponding author <barbarapcsilva@gmail.com>
\end{abstract}

Edited by: Silvia del Carmen Imhoff

Received August 12, 2020

Accepted May 11, 2021
ABSTRACT: Electromagnetic sensors are widely used to monitor soil water content $(\theta)$; however, site-specific calibrations are necessary for accurate measurements. This study compares regression models used for calibration of soil moisture sensors and investigates the relation between soil attributes and the adjusted parameters of the specific calibration equations. Undisturbed soil samples were collected in the A and B horizons of two Ultisols and two Inceptisols from the Mantiqueira Range in Southeastern Brazil. After saturation, the Theta Probe ML2X was used to obtain the soil dielectric constant $(\varepsilon)$. Several readings were made, ranging from saturation to oven-dry. After each reading, the samples were weighted to calculate $\theta\left(\mathrm{m}^{3} \mathrm{~m}^{-3}\right)$. Fourteen regression models (linear, linearized, and nonlinear) were adjusted to the calibration data and checked for their residue distribution. Only the exponential model with three parameters met the regression assumptions regarding residue distribution. The stepwise regression was used to obtain multiple linear equations to estimate the adjusted parameters of the calibration model from soil attributes, with silt and clay contents providing the best relations. Both the specific and the general calibrations performed well, with RMSE values of 0.02 and $0.03 \mathrm{~m}^{3} \mathrm{~m}^{-3}$, respectively. Manufacturer calibration and equations from the literature were much less accurate, reinforcing the need to develop specific calibrations.

Keywords: soil dielectric constant, soil water content, model selection, dielectric-based sensor

\section{Introduction}

Assessing soil water content $(\theta)$ at various spatial and temporal scales is important for a wide range of applications, such as water dynamics and hydrological modeling (Bertoldi et al., 2014; Zhou et al., 2018), management of water resources (Dobriyal et al., 2012), and irrigation planning (Hillel, 2013). Electromagnetic (EM) sensors are a well-established and widely available technique for measuring $\theta$ (Mittelbach et al., 2012). Topp et al. (1980) established the theoretical and practical basis for determining $\theta$ from the soil dielectric constant $(\varepsilon)$, providing an equation for sensor calibration. Although this equation works for a wide range of soils, it may be unsuitable for soils with low bulk density (Regalado et al., 2003; Silva et al., 2012) and with high contents of clay (Kargas et al., 2013), organic matter (Shibchurn et al., 2005), and $\mathrm{Fe}$ and $\mathrm{Al}$ oxides (Kaiser et al., 2010).

Most commercial sensors operate with calibrations specified by their manufacturers (Bogena et al., 2015), which do not take into account specific EM properties inherent to each soil (Kargas et al., 2013; Matula et al., 2016). Accurate assessment of $\theta$ requires calibrations specific to the soils (Feng and Sui, 2020; Mortl et al., 2011; Rowlandson et al., 2013; Stangl et al., 2009) and horizons (Evett et al., 2006). Previous studies on Brazilian soils have been limited to the Cerrado region (Silva et al., 2012), the gently rolling hills of the Southeast (Tomasella and Bachi, 2001) and South (Kaiser et al., 2010), and the semiarid Northeast (Silva et al., 2007). However, there are no calibrations for tropical mountainous soils, which usually have a shallow solum, a deep weathering profile, and high silt and organic matter contents.
Site-specific calibrations are usually performed by adjusting linear (Fares et al., 2011; Kaiser et al., 2010; Rowlandson et al., 2013) and polynomial equations (Kaiser et al., 2010; Matula et al., 2016; Mortl et al., 2011; Sharma et al., 2017). Despite significant models, the analysis of the regression residuals is seldom performed, thus, checking the regression assumptions is critical for linear models; otherwise, the adjusted models may not be valid (Bates and Watts, 1988).

This study investigated the use of linear, linearized, and nonlinear models for calibration of an EM sensor based on electrical impedance to monitor soil moisture. We hypothesized that nonlinear equations properly represent the relation between soil water content and dielectric constant, thus, linear and linearized models may not comply with the regression assumptions regarding residue distribution, which should be addressed in the analyses of the regression residues. We obtained specific and general calibration equations for four soils from the Brazilian Mantiqueira Range, which could be used for other similar soils and equipment (impedance sensors operating at $100 \mathrm{MHz}$ ).

\section{Materials and Methods}

\section{Study site and soil sampling}

The study site is located in the watershed of Posses, in the municipality of Extrema, Minas Gerais State, southeastern Brazil, in the southern boundary of the Mantiqueira Range (Figure 1). This watershed covers an area of 1,200 ha and is a pilot site of the Water Conservation Project, a pioneer initiative established 

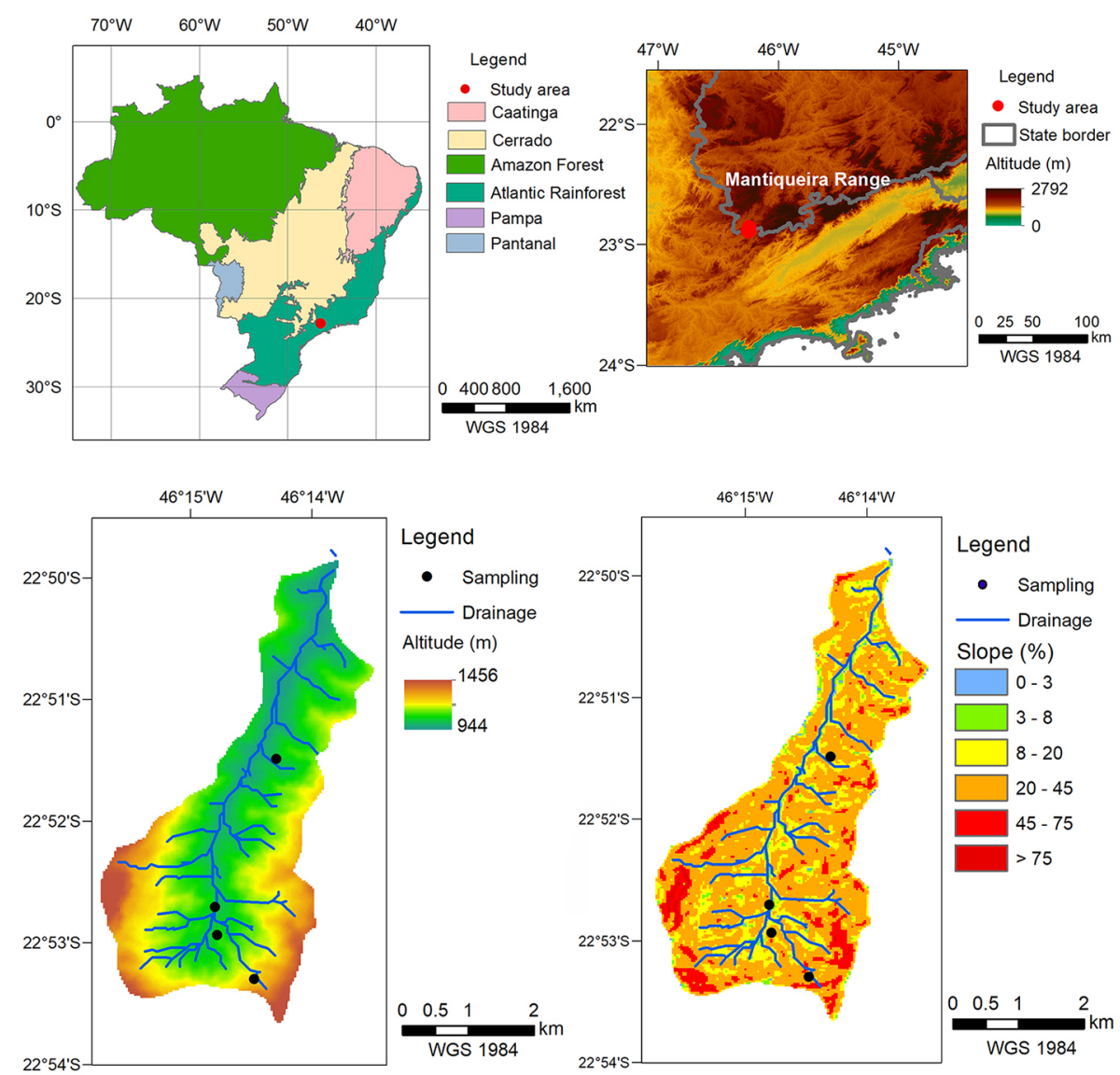

Figure 1 - Location of the study site in the Brazilian Atlantic rainforest biome. Digital elevation models showing the study site in the Mantiqueira Range. Digital elevation models and slope in the watershed of Posses and location of the sampling points next to moisture sensors.

in 2006 to implement payment for ecosystem services in Brazil. Several studies have been conducted in this watershed to monitor hydrological phenomena, which motivated the current study. Soil moisture sensors (model PR2 Profile Probe) have recently been installed and the calibration equations developed here are also used for these field sensors. The local climate is classified as $\mathrm{Cfb}$ (Köppen-Geiger climate classification), mesothermic with no dry season and warm summers (Alvares et al., 2013).

Ultisols and Inceptisols are the dominant soils in the watershed, derived from granulitic orthogneiss (Ultisols and Typic Humudept) or recent alluvialcolluvial sediments weathered and eroded from this same rock (Fluventic Dystrudept) (Silva et al., 2019). The original vegetation is montane ombrophilus forest, a subtype of the Brazilian Atlantic rainforest, but most of the watershed is now covered with Brachiaria-grass pastures (Urochloa decumbens).

Soil samples with undisturbed structure were collected within rigid PVC cylinders $(10 \mathrm{~cm}$ height and $10 \mathrm{~cm}$ diameter) in the $\mathrm{A}$ and $\mathrm{B}$ horizons of the following soil classes (Table 1): Typic Hapludult, Typic Rhodudult, Typic Humudept and Fluventic Dystrudept
(Soil Survey Staff, 2010), which correspond, respectively, to the following soils in the Brazilian classification: Argissolo Vermelho-Amarelo; Argissolo Vermelho; Cambissolo Húmico; and Cambissolo Flúvico (Santos et al., 2018). For the texture analysis, the soil was dispersed in $1 \mathrm{~mol} \mathrm{~L}^{-1} \mathrm{NaOH}$, the sand fraction was separated by sieving (retained in 0.053 $\mathrm{mm}$ opening) and the silt and clay fractions were separated by sedimentation (Donagemma et al., 2017). The clay content was determined with a hydrometer and the silt content was calculated as the remaining fraction. Particle density was determined in volumetric flasks with ethanol (Viana et al., 2017). The OM content was determined by wet oxidation (Fontana and Campos, 2017).

Most sampling sites were in extensive grazing pastures, the major land use in the watershed of Posses, except for the Typic Hapludult, which was sampled in a reforestation site. At each soil and horizon, four undisturbed samples were taken $(4$ soils $\times 2$ horizons $\times 4$ replicates $=32$ samples). Each sample pair (A and B horizons) was taken from a separate trench dug a few meters apart from the soil moisture sensors (PR2 Profile Probe) installed in the field. 
Table 1 - Characterization of the soils and horizons in this study.

\begin{tabular}{|c|c|c|c|c|c|c|c|c|c|}
\hline Soil class & $\mathrm{Hz}$ & Depth & Clay & Silt & Sand & SOM & $\rho_{\mathrm{p}}$ & $\rho_{\mathrm{b}}$ & $n$ \\
\hline \multirow{3}{*}{ Typic Hapludult } & & $\mathrm{cm}$ & - & 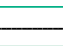 & & - & $\mathrm{Mg} \mathrm{m}^{-3}$ & $\mathrm{Mg} \mathrm{m}^{-3}$ & $\mathrm{~m}^{3} \mathrm{~m}^{-3}$ \\
\hline & A & $0-20$ & 570 & 200 & 230 & 21 & 2.50 & 1.00 & 0.60 \\
\hline & $\mathrm{B}$ & $40-60$ & 650 & 170 & 180 & 14 & 2.56 & 0.87 & 0.66 \\
\hline \multirow{2}{*}{ Typic Rhodudult } & A & $0-20$ & 380 & 140 & 480 & 20 & 2.43 & 1.24 & 0.49 \\
\hline & B & $40-60$ & 590 & 90 & 320 & 11 & 2.53 & 1.05 & 0.58 \\
\hline \multirow{2}{*}{ Typic Humudept } & A & $0-20$ & 410 & 210 & 380 & 31 & 2.58 & 0.85 & 0.67 \\
\hline & B & $40-60$ & 340 & 310 & 350 & 34 & 2.68 & 0.67 & 0.75 \\
\hline \multirow{2}{*}{ Fluventic Dystrudept } & $\mathrm{A}$ & $0-20$ & 80 & 50 & 870 & 5.0 & 2.67 & 1.28 & 0.52 \\
\hline & $B$ & $40-60$ & 220 & 430 & 350 & 16 & 2.34 & 0.97 & 0.58 \\
\hline
\end{tabular}

$\mathrm{Hz}=$ horizon; SOM = soil organic matter; $\rho_{\mathrm{p}}=$ particle density; $\rho_{\mathrm{b}}=$ bulk density; $\mathrm{n}=$ total porosity.

\section{Calibration procedure}

In the laboratory, soil excess was carefully trimmed from the cylinders and a nylon cloth was attached to its bottom to prevent soil losses and allow water evaporation, resulting in a more uniform water content throughout the sample. The undisturbed samples were placed in plastic trays to saturate and gradually filled with water. The calibration procedure for the soil moisture sensor began soon after saturation. The ML2X Theta Probe is an impedance sensor commonly used that generates an electromagnetic signal (100 MHz), which extends to the soil through four metallic rods. This sensor was chosen for its availability, small probe size (compatible with the undisturbed samples used) and same operation frequency as the PR2 Profile Probe installed in the field. The signal generated suffers impedance that depends mostly on the apparent soil dielectric constant (Delta-T Devices, 1999). As the water dielectric constant ( 81) is greater than that of the soil solids (typically from 3 to 5 ) and that of air (1), the soil dielectric constant is defined mostly by its water content (Topp, 2003).

At the beginning of saturation, the ML2X probe was inserted vertically into the soil samples (kept within their PVC containers), and the response signal (in volts) was registered. The probe was inserted and removed from the samples at each reading, a procedure often adopted in calibration studies (Delta-T Devices, 1999). The samples were left to dry in the laboratory to obtain a wide range of water contents and periodical readings with the ML2X sensor were taken. At the beginning, while the soil was close to saturation and the gravitational gradient drained rapidly the water, the readings were taken at $12 \mathrm{~h}$ intervals. The timelapse between consecutive readings increased gradually as the samples dried and the hydraulic conductivity became smaller. Water loss and redistribution were rapid during the first readings (gravity-driven flow), but soon evaporation became the main driver for water loss and the gradient of matrix potential started to account for water redistribution. The samples were weighed following each reading. After the last reading, the samples were oven-dried to determine the dry soil mass to calculate the water content $\theta(\mathrm{v} / \mathrm{v})$ at each calibration step (thermo-gravimetric method) and the soil bulk density (Blake and Hartge, 1986; Klute, 1986).

The sensor response was provided in volts (V) and was converted to the soil apparent dielectric permittivity $(\varepsilon)$ by the third-degree polynomial according to the manufacturer (Eq. 1). Sensor outputs ranged from 0 to $1 \mathrm{~V}$ for all the measurements except for readings on the first day (close to saturation). In this case, the sensor output exceeded $1 \mathrm{~V}$, mainly for the Typic Humudept. This procedure provided several ordered pairs of $\varepsilon$ and $\theta$ (abscissa and ordinate, respectively) for each soil and horizon to perform the calibration, as recommended by the manufacturer (Delta-T Devices, 1999). The calibration equations proposed here could also be used with other EM sensors, such as the PR2 Profile Probes installed in the same study site. According to the manufacturer, the measurements provided as voltage for both sensors may differ, but they could be converted to dielectric constant with specific equations for each equipment (Delta-T Devices, 1999), like Eq. (1).

$$
\varepsilon^{0.5}=1.07+6.4 \mathrm{~V}-6.4 \mathrm{~V}^{2}+4.7 \mathrm{~V}^{3}
$$

\section{Calibration equations and statistical analysis}

The ML2X sensor has a standard calibration provided by the manufacturer, indicated by Eq. (2). Different values for the parameters $a_{0}$ and $a_{1}$ allow using this calibration equation in mineral soils $\left(a_{0}=1.6\right.$ and $\left.a_{1}=8.4\right)$, with the OM content below $7 \%$ and bulk density above 1.0 $\mathrm{Mg} \mathrm{m}^{-3}$, and in organic soils $\left(\mathrm{a}_{0}=1.3\right.$ and $\left.\mathrm{a}_{1}=7.7\right)$, with the OM content above $7 \%$ and bulk density below 1.0 $\mathrm{Mg} \mathrm{m}^{-3}$ (Delta-T Devices, 1999). In the current study, we only used the calibration parameters for mineral soils, since the soil organic matter (SOM) content (Table 1) was much lower (up to $34 \mathrm{~g} \mathrm{~kg}^{-1}$ ) than the content established by the manufacturer $\left(70 \mathrm{~g} \mathrm{~kg}^{-1}\right)$.

$\varepsilon^{0.5}=a_{0}+a_{1} \times \theta$

Unlike the procedure set by the manufacturer (Eq. 2), the calibration equations here are defined as the functional relation that allows transforming $\varepsilon$, provided by the sensor (the sensor actually provides a reading 
in voltage converted to $\varepsilon$ with equation 1 as justified previously), to $\theta\left(\mathrm{m}^{3} \mathrm{~m}^{-3}\right)$, that is, $\varepsilon$ is the independent or predictor variable and $\theta$ is the dependent or response variable. We tested 14 different equations (Table 2), including three linear models (first, second and third degree polynomials), three linear models (first, second and third degree polynomials) with square-root transformation in the predictor variable to stabilize variance (also because this is a common practice in EM sensor calibration), two linearized models (power and exponential models linearized by log transformations), and six nonlinear models (power, exponential and hyperbolic models with two or three parameters).

The models were adjusted to the observed data and the primary analysis investigated the regression assumptions by the residue analysis with graphical procedures (Bates and Watts, 1988). The residues were checked for normality (Q-Q plot), constant variance (plots of square-root of standardized residues $\times$ fitted values for the linear and linearized models and standardized residues $\times$ fitted values for the nonlinear models) and independent distribution (residuals $\times$ fitted values). A single model that best met these criteria was chosen for further analyses.

The best model chosen was investigated to relate its adjusted parameters to the soil attributes from Table 1 to enable the use of the specific calibrations obtained in this study in different similar conditions (same predominantly kaolinitic clay mineralogy, but with different soil texture, OM content, structure, among others). This analysis was conducted by the forward stepwise regression, starting with the simplest model (with only the intercept) and proceeding to the full model (with all of the attributes from Table 1). The soil attributes were kept in the model according to the Akaike information criteria.

The model performance was compared in terms of the mean bias error (MBE) (Eq. 3), which indicates under- and overestimation by the model, and the root mean squared error (RMSE) (Eq. 4), which indicates overall agreement between predicted and observed values in the same unit as the data (in this case, $\mathrm{m}^{3} \mathrm{~m}^{-3}$ since the objective is to predict soil moisture).

MBE $=\frac{\Sigma(\text { Predicted }- \text { observed })}{\text { Number of observations }}$
MBE $=\sqrt{\frac{\sum(\text { Predicted }- \text { observed })^{2}}{\text { Number of observations }}}$

For the specific calibration equations, RMSE values were also calculated for all the data in each soil and horizon and using 10-fold cross-validation. Data for each soil and horizon was randomly partitioned into 10 divisions. The regression model was fitted to nine of the partitions at each time and the RMSE was calculated using the observed and predicted values of the $10^{\text {th }}$ partition.

Table 2 - Models tested in this study and from the manufacturer and the literature.

\begin{tabular}{|c|c|c|c|}
\hline \multicolumn{4}{|c|}{ Models tested in the present study } \\
\hline ID & \multicolumn{2}{|c|}{ Models } & Equations \\
\hline 1 & \multicolumn{2}{|l|}{ Linear } & $\theta=a+b \varepsilon$ \\
\hline$\|$ & \multicolumn{2}{|l|}{ Linear (polynomial $2^{\text {nd }}$ degree) } & $\theta=a+b \varepsilon+c \varepsilon^{2}$ \\
\hline III & \multicolumn{2}{|l|}{ Linear (polynomial $3^{\text {rd }}$ degree) } & $\theta=a+b \varepsilon+c \varepsilon^{2}+d \varepsilon^{3}$ \\
\hline IV & \multicolumn{2}{|c|}{ Linear - square root transformation } & $\theta=a+b \sqrt{\varepsilon}$ \\
\hline V & \multicolumn{2}{|c|}{ Linear (polynomial $2^{\text {nd }}$ degree) - square root transformation } & $\theta=a+b \sqrt{\varepsilon}+b \sqrt{\varepsilon}^{2}$ \\
\hline $\mathrm{Vl}$ & \multicolumn{2}{|c|}{ Linear (polynomial $3^{\text {rd }}$ degree) - square root transformation } & $\theta=a+b \sqrt{\varepsilon}+c \sqrt{\varepsilon}^{2}+d \sqrt{\varepsilon}^{3}$ \\
\hline VII & \multicolumn{2}{|c|}{ Linearized (power) } & $\ln \theta=a+b \varepsilon$ \\
\hline VIII & \multicolumn{2}{|l|}{ Linearized (exponential) } & $\ln \theta=\ln a+b \ln \varepsilon$ \\
\hline IX & \multicolumn{2}{|l|}{ Nonlinear (power) } & $\theta=a(1+\varepsilon)^{b}$ \\
\hline$x$ & \multicolumn{2}{|l|}{ Nonlinear (power) } & $\theta=1+\frac{1}{(1+a \varepsilon)^{b}}$ \\
\hline $\mathrm{XI}$ & \multicolumn{2}{|l|}{ Nonlinear (exponential) } & $\theta=a\left(1-e^{(b s)}\right)$ \\
\hline XII & \multicolumn{2}{|l|}{ Nonlinear (exponential) } & $\theta=a\left(1-b^{\varepsilon}\right)$ \\
\hline XIII & \multicolumn{2}{|l|}{ Nonlinear (exponential) } & $\theta=a+b\left(1-c^{\varepsilon}\right)$ \\
\hline XIV & \multicolumn{2}{|l|}{ Nonlinear (hyperbolic) } & $\theta=a+\frac{\varepsilon}{b+\varepsilon}$ \\
\hline \multicolumn{4}{|c|}{ Models taken the manufacturer and other studies } \\
\hline \multicolumn{3}{|l|}{ Reference } & \\
\hline \multicolumn{2}{|l|}{ Topp et al. (1980) } & \multicolumn{2}{|c|}{$\theta=-5.3 \times 10^{-2}+2.92 \times 10^{-2} \varepsilon-5.5 \times 10^{-4} \varepsilon^{2}+4.3 \times 10^{-6} \varepsilon^{3}$} \\
\hline Malicki et al. (1996) & \multicolumn{3}{|c|}{$\theta=\frac{\sqrt{\varepsilon}-0.819-0.168 \rho-0.159 \rho^{2}}{7.17+1.18 \rho}$} \\
\hline \multicolumn{2}{|l|}{ Vaz (2008) } & \multicolumn{2}{|c|}{$\theta=-3.166 \times 10^{-2}+3.317 \times 10^{-2} \varepsilon-9.178 \times 10^{-4} \varepsilon^{2}+1.130 \times 10^{-5}$} \\
\hline Manufacter & \multicolumn{3}{|c|}{$\varepsilon^{0.5}=a_{0}+a_{1} \times \theta$} \\
\hline
\end{tabular}

$\varepsilon=$ Dielectric constant; $\theta=$ volumetric water content $\left(\mathrm{m}^{3} \mathrm{~m}^{-3}\right) ; \rho=$ bulk density $\left(\mathrm{Mg} \mathrm{m}^{-3}\right)$. 
This procedure was repeated 10 times for each soil and horizon and the mean RMSE value was then calculated.

All the statistical procedures were performed in $\mathrm{R}$ statistical software using basic functions and the package nls.tools (Baty; Delignette-Muller, 2015) to obtain the residue distributions. The model chosen to perform the calibration was compared with models from the manufacturer and the literature (Table 2).

\section{Results and Discussion}

\section{Calibration models: quality assessment and model selection}

The different models varied greatly regarding the residue distribution (Table 3). Most models met the assumption of residue normality (observed in more than $50 \%$ of the fitted equations for almost all 14 models tested), while constant variance and independence between the residues were more difficult to meet. These assumptions are especially important for linear models, because if they are violated, the resultant analysis may not be valid (Bates and Watts, 1988).

These criteria are related to the assumption of identically and independently distributed residues. The normal distribution is a description of the randomness of these errors and this assumption was more easily met because often only minor deviations were observed in the Q-Q plots. The non-constant variance and autocorrelation indicate that the regression residues are not identically and independently distributed, that is, the magnitude of the errors changes as the predictor variable changes (variance is not constant) or the residues present some sort of structure, with higher or lower values occurring together (correlated to each other).

Table 3 - Models tested in this study, percentage of models that met the assumptions of residue normality, constant variance, and independent distribution.

\begin{tabular}{lcrcc}
\hline Models & Identifier & Normality & $\begin{array}{c}\text { Constant } \\
\text { variance }\end{array}$ & $\begin{array}{c}\text { Independent } \\
\text { distribution }\end{array}$ \\
\hline$\theta=a+b \varepsilon$ & I & 62.5 & 25.0 & 0.00 \\
$\theta=a+b \varepsilon+c \varepsilon^{2}$ & II & 100.0 & 25.0 & 37.5 \\
$\theta=a+b \varepsilon+c \varepsilon^{2}+d \varepsilon^{3}$ & III & 100.0 & 25.0 & 37.5 \\
$\theta=a+b \sqrt{\varepsilon}$ & IV & 75.0 & 0.00 & 0.00 \\
$\theta=a+b \sqrt{\varepsilon}+b \sqrt{\varepsilon}^{2}$ & V & 100.0 & 37.5 & 37.5 \\
$\theta=a+b \sqrt{\varepsilon}+c \sqrt{\varepsilon}^{2}+d \sqrt{\varepsilon}^{3}$ & VI & 100.0 & 12.5 & 25.0 \\
$\ln \theta=a+b \varepsilon$ & VII & 50.0 & 0.00 & 0.00 \\
$\ln \theta=\ln a+b \ln \varepsilon$ & VIII & 87.5 & 0.00 & 0.00 \\
$\theta=a(1+\varepsilon)^{b}$ & IX & 62.5 & 0.00 & 62.5 \\
$\theta=1+\frac{1}{(1+a \varepsilon)^{b}}$ & X & 62.5 & 37.5 & 62.5 \\
$\theta=a\left(1-e^{(b \varepsilon)}\right.$ & XI & 62.5 & 50.0 & 62.5 \\
$\theta=a\left(1-b^{\varepsilon}\right)$ & XII & 62.5 & 50.0 & 62.5 \\
$\theta=a+b\left(1-c^{\varepsilon}\right)$ & XIII & 100.0 & 100.0 & 100.0 \\
$\theta=a+\frac{\varepsilon}{b+\varepsilon}$ & XIV & 75.0 & 50.0 & 75.0 \\
\hline
\end{tabular}

The failure to meet these assumptions may indicate model inadequacy to fit the data, possibly due to lack of a nonlinear term in a linear model or fitting a non-asymptotic model (e.g. polynomial) to an asymptotic phenomenon. The common procedure to calibrate sensors involves taking repeated measurements from the same sample, which may lead to auto correlated residues. The exponential model (model XIII) with three parameters had the best performance, meeting the criteria in all the fittings (Table 3), followed by the hyperbolic model (model XIV).

Electromagnetic sensors calibration is usually performed with linear models and the second- and thirddegree polynomials are the most common (Fares et al., 2011; Matula et al., 2016; Mortl et al., 2011; Vaz et al., 2013). However, most studies do not check the regression assumptions, although the uncertainty analysis or other forms of validation are sometimes performed (Logsdon et al., 2009; Vaz et al., 2013). Table 3 shows that these assumptions are frequently violated by most models, indicating the strong need to perform this check after fitting.

\section{Exponential model: interpretation and relevance}

Model XIII was chosen to perform the calibration, despite some disadvantages of this model. Its intercept term (the "a" parameter) frequently resulted in negative values thus indicating negative water contents for $\varepsilon$ values close to zero. This is only a theoretical concern, because the smallest possible value for $\varepsilon$ is 1.0 (for vacuum). However, as $\varepsilon$ for the soil solids (i.e. dry soil) is within the range of 3 to 8 (Hillel, 1998; Topp, 2003) and the model did not return negative values of $\theta$ for these $\varepsilon$ values, there are no practical concerns about physical inadequacies. The only practical consequence of this fact is that this parameter may lack some meaningful interpretation. This was the only parameter with some non-significant values and presented the highest standard errors, while for the " $\mathrm{b}$ " and " $\mathrm{c}$ " parameters the standard errors were within the range of 1.7-4.8\% and $0.4-1.3 \%$ of their estimated values respectively (Table 4). Nevertheless, the inclusion of this intercept term is essential for the model performance, as the other exponential models without this term (models XI and XII) had a poor performance in the residue analysis (Table 3).

Parameter " $\mathrm{c}$ " controls the model curvature: the lower its value (Table 4), the sharper the model initial ascent (Figure 2), while higher values (closer to one) are related to a smoother rise. Parameter " $b$ " is multiplicative and is related to the change rate in the response variable for each unitary change in the independent variable. However, parameters "b" and "c" are correlated to each other $(\mathrm{r}=-0.83)$ and should not be analyzed separately. This does not mean they are redundant, as they obviously perform unique effects in the equation ("c" is for curvature and "b" is multiplicative), but that 
Typic Hapludult

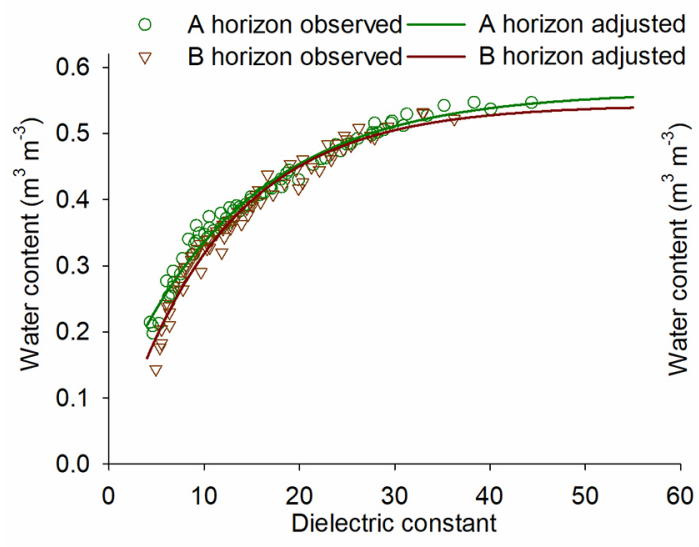

Fluventic Dystrudept

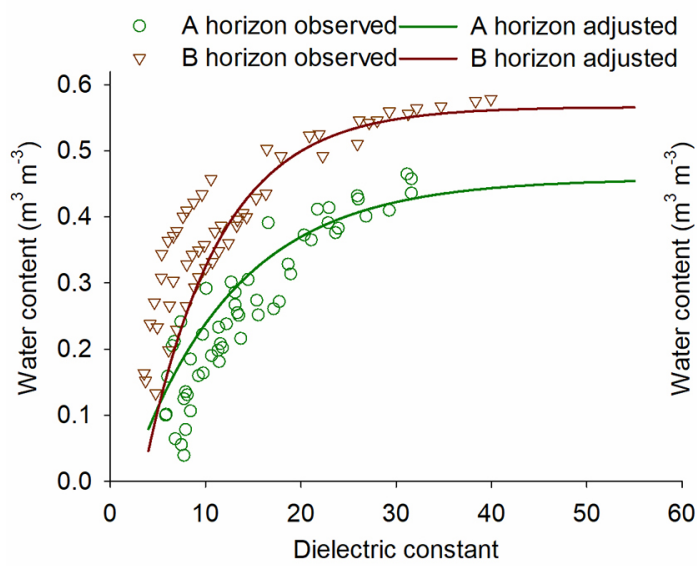

Typic Rhodudult

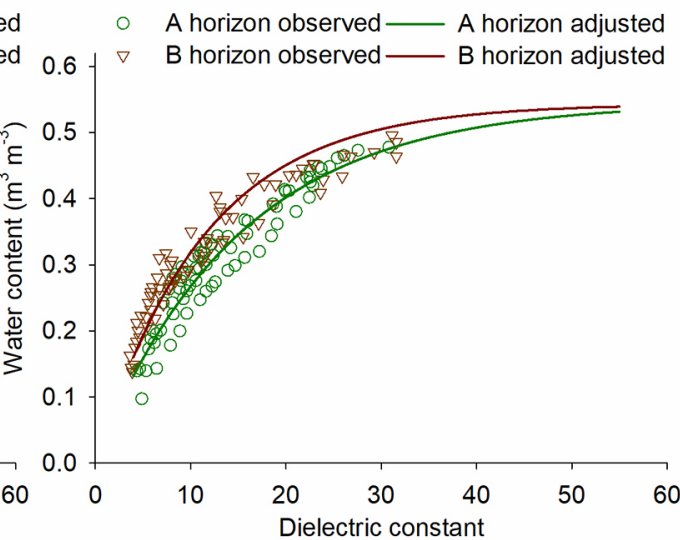

Typic Humudept

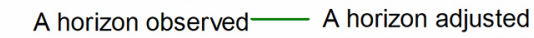

$\nabla \quad B$ horizon observed- B horizon adjusted

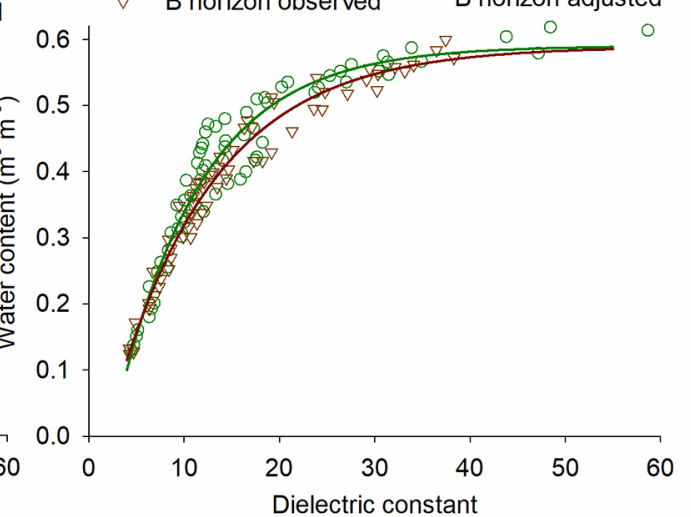

Figure 2 - Observed data and adjusted calibration equations for the different soils and horizons. The adjusted parameters of the exponential models are shown in Table 4.

Table 4 - Estimated parameters ("a", "b" and "c") for the chosen exponential model (Table 2, model XIII), standard error of estimated parameters and number of data points from the calibration procedure of the models for each soil class and horizon.

\begin{tabular}{|c|c|c|c|c|c|c|c|c|}
\hline \multirow{2}{*}{ Soil class } & \multirow{2}{*}{$\mathrm{Hz}$} & \multicolumn{2}{|c|}{ "a" parameter } & \multicolumn{2}{|c|}{ "b" parameter } & \multicolumn{2}{|c|}{ "c" parameter } & \multirow{2}{*}{ N. obs ${ }^{*}$} \\
\hline & & Estimated value & Standard error & Estimated value & Standard error & Estimated value & Standard error & \\
\hline \multirow{2}{*}{ Typic Hapludult } & $A$ & $0.090^{* * *}$ & 0.012 & $0.474^{* * *}$ & 0.008 & $0.929^{* * *}$ & 0.004 & 72 \\
\hline & B & $-0.003^{\text {ns }}$ & 0.020 & $0.546^{* * *}$ & 0.014 & $0.915^{* * *}$ & 0.006 & 73 \\
\hline \multirow{2}{*}{ Typic Rhodudult } & A & $0.006^{\text {ns }}$ & 0.029 & $0.539^{* * *}$ & 0.023 & $0.936^{* * *}$ & 0.012 & 72 \\
\hline & $\mathrm{B}$ & $0.042^{* *}$ & 0.021 & $0.453^{* * *}$ & 0.015 & $0.912^{* * *}$ & 0.010 & 72 \\
\hline \multirow{2}{*}{ Typic Humudept } & A & $-0.175^{* \star *}$ & 0.042 & $0.766^{* * *}$ & 0.037 & $0.895^{* * *}$ & 0.007 & 54 \\
\hline & $\mathrm{B}$ & $-0.100^{* * *}$ & 0.026 & $0.690 * * *$ & 0.021 & $0.911^{* * *}$ & 0.006 & 51 \\
\hline \multirow{2}{*}{ Fluventic Dystrudept } & A & $-0.088^{* *}$ & 0.029 & $0.545^{* * *}$ & 0.023 & $0.913^{* * *}$ & 0.010 & 65 \\
\hline & B & $-0.302^{* * *}$ & 0.031 & $0.868^{* * *}$ & 0.028 & $0.880^{* * *}$ & 0.005 & 65 \\
\hline
\end{tabular}

$\mathrm{Hz}=$ soil horizon; ${ }^{*}$ Number of observations in each model; ${ }^{*}$ Significant at $5 \%(p<0.05) ;{ }^{* *}$ Significant at $1 \%(p<0.01)$; ns $=$ not significant $(p>0.05)$.

they work together: a smoothest initial rise (higher "c") is related to a lower change rate in $\theta$ for each increment in $\varepsilon$ (lower "b").

The models from both Inceptisols presented a sharp initial rise (Figure 2) due to higher values of " $b$ " and lower values of "c" (Table 4). The soil dielectric constant rapidly increased with increasing water content, then stabilizing at $\varepsilon$ values around $15-20$, when the change rate decreased. Therefore, a linear relation between $\theta$ and $\varepsilon$ only exists for $\theta$ values up to approximately $0.3-0.4 \mathrm{~m}^{3}$ $\mathrm{m}^{-3}$. For the other soils, the initial rise of the model was not as sharp, following a clear nonlinear trend starting at low values of $\theta$ and $\varepsilon$. The inclination of the calibration curves for the Ultisols (indicate the change rate in $\theta$ for 
each increment in $\varepsilon$ ) markedly decreased at $\varepsilon$ values of 20-30. These $\varepsilon$ values correspond to $\theta$ values close to $0.4-$ $0.5 \mathrm{~m}^{3} \mathrm{~m}^{-3}$, indicating that the departure from a linear trend is more conspicuous when the soil is wetter than this range. The manufacturer, however, claims that their linear calibration equation may work for $\theta$ as high as $0.55 \mathrm{~m}^{3} \mathrm{~m}^{-3}$ (Delta-T Devices, 1999), which is clearly not corroborated by our results (the relation departs from linear when $\theta$ is lower).

The studied soils are in a catena with Typic Rhodudult at the summit, Typic Hapludult in more gentle slopes, Typic Humudept in steep slopes, and the Fluventic Dystrudepts in the foot slope. Although they occur close to each other, the soils presented notable differences in their calibration equations (see Table 4 for adjusted parameters and Figure 2 for calibration curves) because of the differences in their soil attributes (Table 1). Additionally, great differences in the calibration equations may exist within the same soil profile, such as the A and B horizons of the Fluventic Dystrudept, which were highly different in their calibration model (Figure 2), because they are inherently different in their soil attributes (Table 1). These results allow a better understanding of the importance of specific calibrations, since the relation between $\theta$ and $\varepsilon$ is specific to each soil and horizon. Another aspect of the calibration equations that becomes very clear is how much they depart from a linear trend. Possibly, this relation could be represented by a straight line for a narrow range of water contents, as is the case for the manufacturer calibration (Delta-T Devices, 1999). However, a model with such a narrow range has little value for monitoring soil moisture, which may range from saturation to almost dry conditions.

\section{Influence of soil attributes in the general calibration model}

As the soils and horizons differed in their calibration equations (Figure 2), the relation between these equations and the soil attributes was investigated by the stepwise linear regressions to develop a more general calibration equation. Although these calibrations are only empirical equations without any clear physical meaning, this approach may help the general use of our results to other similar soils. Significant equations were obtained (Table 5), which allow estimating the parameters for the exponential model from the soil attributes. Although the linear equation for parameter "c" was non-significant, the linear correlation coefficient of 0.62 indicates a fair agreement degree between both variables.

The silt content was the most important soil attribute affecting the exponential model parameters, as it was the first variable incorporated by the stepwise regression. This is surprising because the manufacturer (Delta-T Devices, 1999) and most studies usually highlight the effect of the OM content and bulk density as the most important for this type of model (Jacobsen and Schjonning, 1993; Jin et al., 2017; Malicki et al., 1996; Silva et al., 2019). Some studies have also discussed the effect of soil texture on sensor calibration (Kargas et al., 2013; Zanetti et al., 2015), but without acknowledging the importance of silt. The silt content is a very important soil attribute to understand the physical properties and erosion resistance of tropical mountainous soils, being related to soil water retention capacity (Costa et al., 2013) and aggregate stability (Sung, 2012). The clay content was the second most important soil attribute in the stepwise regression, reinforcing the importance of soil texture in defining the relation between soil moisture and its dielectric constant.

The equation to predict parameter "c" had the worst performance in terms of its coefficient of determination of only 0.38 (Table 5); nevertheless, it presented the lowest standard error 0.015 or only $1.6 \%$ of the average observed values). Because this parameter presented the smallest amplitude (only 0.034, with an average value of 0.91 ), the equation from Table 5 was still capable of delivering fair estimates for this parameter, despite its poor performance (Figure 3). The equation for estimating parameter " $b$ " presented the highest coefficient of determination (0.79) and depicted a rather low standard error of only $13 \%$ of the average parameter value (standard error of 0.08 and average value of 0.61). The equations in Table 5 usually performed poorly in the Typic Humudept and in the A horizons in general (Figure 3), indicating a possible effect of $\mathrm{OM}$ or even structure that was not captured by the stepwise regression. The OM content and bulk density are also important attributes affecting calibration and performance of electromagnetic sensors to measure the soil water content (Jacobsen and Schjonning, 1993; Jin et al., 2017; Malicki et al., 1996; Silva et al., 2019). The lack of significance for these parameters may be due to the small number of observations, since these parameters came from the eight calibration equations fitted to model XIII (one for each soil and horizon).

Table 5 - Linear equations to estimate the parameters of the exponential model (model XIII in Table 2) from soil attributes for the general calibration model (using all data).

\begin{tabular}{lllll}
\hline Parameter & \multicolumn{1}{c}{ Equation } & $p$-value & $\mathrm{R}^{2}$ & $\sigma$ \\
\hline $\mathrm{a}$ & $\mathrm{a}=-0.086-0.006 \times$ Silt $+0.004 \times$ Clay & $0.029^{*}$ & 0.756 & 0.075 \\
$\mathrm{~b}$ & $\mathrm{~b}=0.535+0.009 \times$ Silt $-0.003 \times$ Clay & $0.019^{*}$ & 0.794 & 0.080 \\
$\mathrm{c}$ & $\mathrm{c}=0.929-0.001 \times$ Silt & $0.102^{\text {ns }}$ & 0.383 & 0.015 \\
\hline
\end{tabular}

Silt $=$ silt content (\%); Clay $=$ clay content $(\%) ; \sigma=$ residual standard error. ${ }^{*}$ Significant at $5 \%(p<0.05)$; ns $=$ not significant $(p>0.05)$. 


\section{Accuracy improvements with specific and general calibration models}

The specific calibration improved the estimation of $\theta$ for all the soils and horizons in comparison to the other equations tested (Table 6). The manufacturer establishes a RMSE value of $0.05 \mathrm{~m}^{3} \mathrm{~m}^{-3}$ as a threshold for acceptable calibration error (Delta-T Devices, 1999). Only the specific and the general calibrations are considered adequate for all the soils and horizons. The RMSE values for the specific calibrations ranged from 0.013 to $0.032 \mathrm{~m}^{3} \mathrm{~m}^{-3}$ considering all the data for each soil and horizon and from 0.001 to $0.01 \mathrm{~m}^{3} \mathrm{~m}^{-3}$ for the 10 -fold cross-validation, whereas the RMSE ranged from 0.02 to $0.05 \mathrm{~m}^{3} \mathrm{~m}^{-3}$ for the general calibration (Table 6).

According to MBE and RMSE values, the performance of calibrations was as follows: specific > general > Malicki et al. (1996) > Vaz (2008) > Topp et al. (1980) manufacturer. The calibration equation from Malicki et al. (1996) also outperformed the calibration from Topp et al. (1980) in other studies with tropical soils (Coelho et al., 2006; Teixeira et al., 2003). In a previous study, Jacobsen and Schjonning (1993) detected improvements of TDR calibrations with the inclusion of soil bulk density, which explains the outperformance of the equation from Malicki et al. (1996) in relation to the others.

These results reinforce the importance of employing specific calibrations for EM sensors or at least general calibrations that properly represent the soils studied. The adequate performance of the specific and general calibrations proposed here can also be noted by their fair agreement to the 1:1 line (Figure 4); however, rather less accurate for the A horizons of both Inceptisols.

The calibration equations from other studies often underestimated $\theta$ with most points remaining below the 1:1 line (Figure 4). This underestimation averaged from 0.02 to $0.14 \mathrm{~m}^{3} \mathrm{~m}^{-3}$ (Table 6). Other studies, including in tropical soils, have also shown that the calibration from Topp et al. (1980) usually underestimates $\theta$ (Fares et al., 2011; Teixeira et al., 2003; Tommaselli and Bacchi, 2001; Silva et al., 2019). The underestimation worsens the lower the soil bulk density (Regalado et al., 2003), also observed for the Typic Humudept (Figure 4).

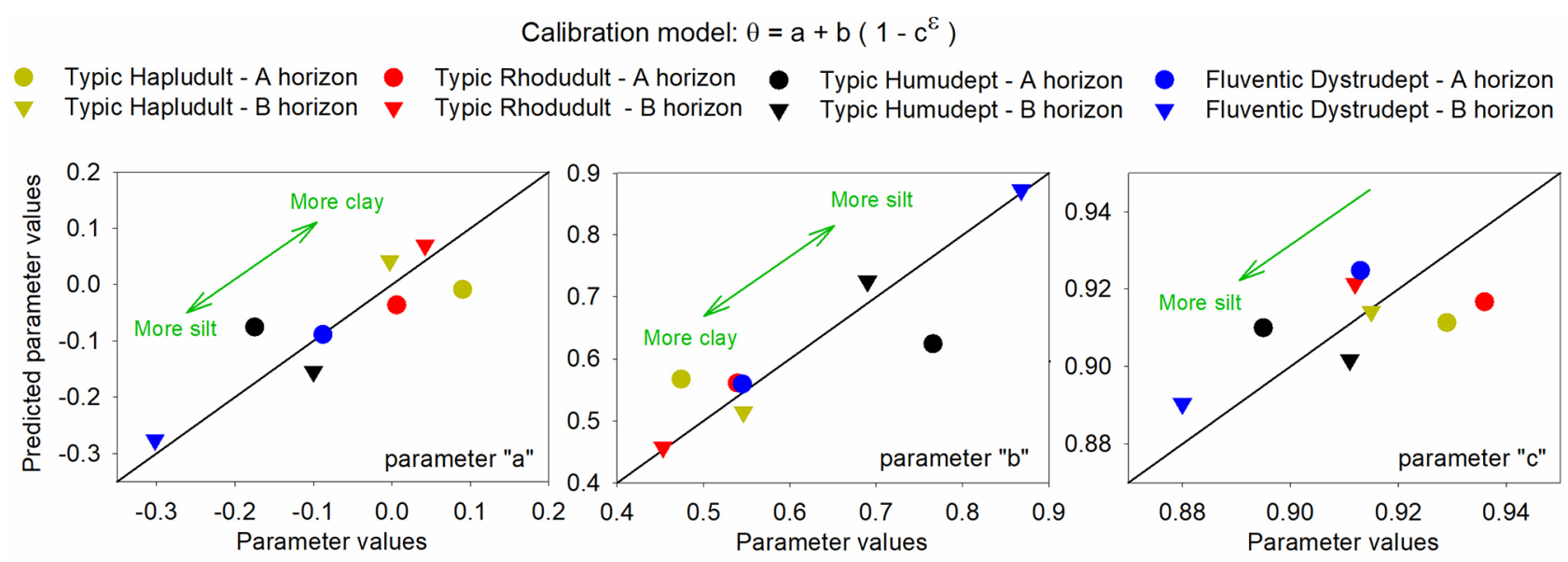

Figure 3 - Prediction of the calibration model parameters from the soil attributes (clay and silt contents), showing the ordinate pairs of observed (Table 4) and predicted (equations from Table 5) parameter values, 1:1 lines, and the significant soil attributes for each parameter (the arrows indicate direct or inverse tendencies between the predicted parameter and the attributes).

Table 6 - Mean bias error (MBE) and root mean squared error (RMSE) to estimate $\theta$ from $\varepsilon$ with different calibration equations.

\begin{tabular}{|c|c|c|c|c|c|c|c|c|c|c|c|c|c|c|}
\hline \multirow{2}{*}{ Soil class } & \multirow{2}{*}{$\mathrm{Hz}$} & \multicolumn{3}{|c|}{ Specific calibration } & \multicolumn{2}{|c|}{ General calibration } & \multicolumn{2}{|c|}{ Manufacturer } & \multicolumn{2}{|c|}{ Topp et al. (1980) } & \multicolumn{2}{|c|}{ Malicki et al. (1996) } & \multicolumn{2}{|c|}{ Vaz (2008) } \\
\hline & & MBE & $\mathrm{RMSE}^{1}$ & $\mathrm{RMSE}^{2}$ & MBE & RMSE & MBE & RMSE & MBE & RMSE & MBE & RMSE & MBE & RMSE \\
\hline \multirow{2}{*}{$\begin{array}{l}\text { Typic } \\
\text { Hapludult }\end{array}$} & A & $<0.001$ & 0.013 & 0.001 & 0.003 & 0.020 & -0.12 & 0.127 & -0.11 & 0.125 & -0.06 & 0.078 & -0.10 & 0.104 \\
\hline & B & $<0.001$ & 0.016 & 0.001 & 0.02 & 0.030 & -0.11 & 0.117 & -0.11 & 0.115 & -0.04 & 0.055 & -0.09 & 0.094 \\
\hline \multirow{2}{*}{$\begin{array}{l}\text { Typic } \\
\text { Rhodudult }\end{array}$} & A & $<0.001$ & 0.026 & 0.003 & 0.02 & 0.034 & -0.07 & 0.078 & -0.07 & 0.076 & -0.04 & 0.05 & -0.05 & 0.054 \\
\hline & B & $<0.001$ & 0.023 & 0.004 & 0.01 & 0.028 & -0.11 & 0.117 & -0.11 & 0.115 & -0.06 & 0.075 & -0.08 & 0.089 \\
\hline \multirow{2}{*}{$\begin{array}{l}\text { Typic } \\
\text { Humudept }\end{array}$} & A & $<0.001$ & 0.032 & 0.010 & -0.04 & 0.055 & -0.13 & 0.15 & -0.14 & 0.149 & -0.06 & 0.092 & -0.09 & 0.14 \\
\hline & $\mathrm{B}$ & $<0.001$ & 0.026 & 0.007 & -0.01 & 0.027 & -0.10 & 0.129 & -0.10 & 0.125 & -0.01 & 0.091 & -0.04 & 0.243 \\
\hline \multirow{2}{*}{$\begin{array}{l}\text { Fluventic } \\
\text { Dystrudept }\end{array}$} & A & $<0.001$ & 0.029 & 0.003 & -0.01 & 0.035 & -0.03 & 0.056 & -0.02 & 0.05 & 0.002 & 0.046 & -0.02 & 0.037 \\
\hline & B & $<0.001$ & 0.014 & 0.002 & 0.01 & 0.020 & -0.12 & 0.134 & -0.13 & 0.134 & -0.07 & 0.079 & -0.11 & 0.112 \\
\hline
\end{tabular}

$\mathrm{Hz}=$ soil horizon; ${ }^{1}$ Calculated from all the data; ${ }^{2}$ Calculated from 10 -fold cross-validations. 
- Typic Hapludult - A $○$ Typic Rhodudult - A $\circ$ Typic Humudept - A $\bigcirc$ Fluventic Dystrudept-A

$\Delta \quad$ Typic Hapludult - B $\Delta$ Typic Rhodudult - B $\Delta$ Typic Humudept - B $\Delta \quad$ Fluventic Dystrudept-B

- 1:1 Line
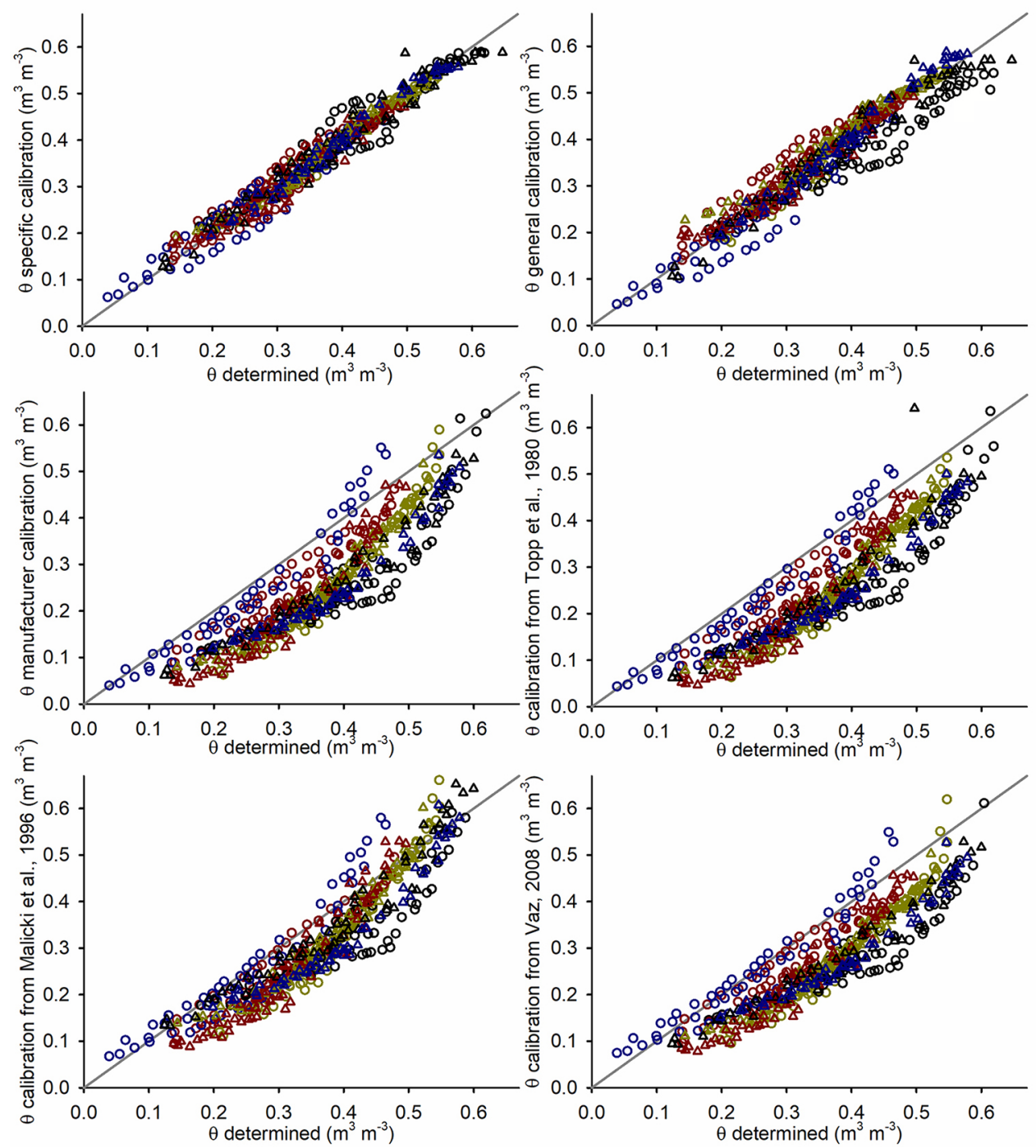

Figure 4 - Relation between the determined soil moisture $(\theta, v / v)$ and the values estimated from the different calibration equations (Tables 3 and 4$)$.

However, some studies have reported overestimation of $\theta$ (Huang et al., 2004; Kargas and Kerkides, 2008). These equations also overestimated $\theta$ in tropical soils with high Fe content (Kaiser et al., 2010), because of its interference in the propagation velocity of electromagnetic waves (Tomaselli and Bacchi, 2001).

The calibration equations from the literature performed better in the A horizons of the Typic Rhodudult and the Fluventic Dystrudept, which present the highest sand contents and the highest bulk densities. Kargas et al. (2013) pointed out that the equation from Topp et al. (1980) was satisfactory only for a material composed entirely of sand because dielectric dispersion (from clay and silt particles) and the effect of soil electric conductivity may have increased the apparent permittivity for the lowfrequency TDR sensor tested (TDR300, operating frequency $<100 \mathrm{MHz}$ ). Since the ML2X probe used in our study has an operating frequency of $100 \mathrm{MHz}$, the equation from Topp et al. (1980) works better for soils less prone to increased electrical permittivity due to the dielectric dispersion of clay. Feng and Sui (2020) also reported that the manufacturer's calibration for TDR only achieved satisfactory results for sandy loam soils. Literature calibrations had the worst performance in the Typic Humudept (especially in the A horizon), which is the soil with the lowest bulk density and the highest OM content. Figure 4 also reinforces another important aspect previously discussed that the polynomial models may not be fit for electromagnetic 
sensor calibration. For $\theta$ values close to saturation, the literature models, especially Malicki et al. (1996), shifted from underestimating to overestimating $\theta$. For example, the calibration from Vaz (2008) indicated $\theta$ values above $1.00 \mathrm{~m}^{3} \mathrm{~m}^{-3}$ in the $B$ horizon of the Typic Humudept and resulted in the highest RMSE value $\left(0.243 \mathrm{~m}^{3} \mathrm{~m}^{-3}\right)$. The polynomial model is not asymptotic and indicates a continuous growth in the relation between $\theta$ and $\varepsilon$. The exponential model used in this study is asymptotic and therefore better represents the actual relation between $\theta$ and $\varepsilon$ near saturation.

\section{Conclusion}

The exponential model performed better than the other models tested, not only because it more properly meets the regression assumptions for residue distribution, but also because its asymptotic behavior better represents the relation between the soil water content and its dielectric constant.

The adjusted parameters of the exponential model were significantly related to the soil attributes. Three linear equations were obtained to predict these parameters from the silt and clay contents.

The specific calibration equations performed the best, with an average error of only $0.02 \mathrm{~m}^{3} \mathrm{~m}^{-3}$, while the general calibration equation (with the parameters estimated from soil attributes) also performed well, with an error of $0.03 \mathrm{~m}^{3} \mathrm{~m}^{-3}$. Both accuracy errors are considered below the threshold levels.

Calibrations from the manufacturer and the literature failed to provide accurate estimates, reinforcing the strong need to perform specific calibrations or apply these general calibrations only to soils similar to their parent soils.

\section{Acknowledgments}

This research was funded by Coordination for the Improvement of Higher Level Personnel (CAPES) Finance Code 001, CAPES/ANA 88887.144979/201700, Academic Excellence Program - PROEX (AUXPE 593/2018); the Brazilian National Council for Scientific and Technological Development (CNPq) - Process $n^{\circ}$ 306511/2017-7 and 202938/2018-2; the Minas Gerais State Agency for Research and Development (FAPEMIG) - Process n ${ }^{\circ}$ APQ-00802-18 and CAGAPQ-01053-15; and the São Paulo State Research Support Foundation (FAPESP) - Projects 2019/23853-5, 2017/50241-5 and IAEA/CRPD12014-CN23713.

\section{Authors' Contributions}

Conceptualization: Silva, B.P.C.; Tassinari, D. Data acquisition: Silva, B.P.C.; Silva, M.L.N. Data analysis: Silva, B.P.C.; Tassinari, D. Design of methodology: Silva, B.P.C.; Tassinari, D.; Silva, B.M. Writing and editing: Silva, B.P.C.; Tassinari, D.; Silva, B.M.; Silva, M.L.N.; Curi, N.

\section{References}

Alvares, C.A.; Stape, J.L.; Sentelhas, P.C.; Gonçalves, J.L.M.; Sparovek, G. 2013. Köppen's climate classification map for Brazil. Meteorologische Zeitschrift 22: 711-728.

Bates, D.M.; Watts, D.G. 1988. Nonlinear Regression Analysis and Its Applications. John Wiley, New York, NY, USA.

Baty, F.; Delignette-Muller, M.L. 2015. nlstools: tools for nonlinear regression analysis. R package version 1.0-2. Available at: http:// CRAN.R-project.org/package $=$ nlstools $[$ Accessed Apr 10, 2021]

Bertoldi, G.; Chiesa, S.D.; Notarnicola, C.; Pasolli, L.; Niedrist, G.; Tappeiner, U. 2014. Estimation of soil moisture patterns in mountain grasslands by means of SAR RADARSAT2 images and hydrological modelling. Journal of Hydrology 516: 245-257.

Blake, G.R.; Hartge, K.H. 1986. Bulk density. p. 363-376. In: Klute, A., ed. Methods of soil analysis. Part 1. Physical and mineralogical methods. 2ed. ASA/SSSA, Madison, WI, USA.

Bogena, H.R.; Huisman, J.A.; Güntner, A.; Hübner, C.; Kusche, J.; Jonard, F.; Vey, S.; Vereecken, H. 2015. Emerging methods for noninvasive sensing of soil moisture dynamics from field to catchment scale: a review. Wiley Interdisciplinary Reviews: Water 2: 635-647.

Coelho, E.F.; Vellame, L.M.; Coelho Filho, M.A.; Ledo, C.A.S. 2006. Performance of calibration models for TDR and multiplexer: connected waveguides in three soil types. Revista Brasileira de Ciência do Solo 30: 23-30 (in Portuguese, with abstract in English).

Costa, A.; Albuquerque, J.A.; Costa, A.; Pértile, P.; Silva, F.R. 2013. Water retention and availability in soils of the State of Santa Catarina-Brazil: effect of textural classes, soil classes and lithology. Revista Brasileira de Ciência do Solo 37: 1535-1548.

Delta-T Devices. 1999. Theta Probe Soil Moisture Sensor - ML2x: User Manual. Delta-T Devices, Cambridge, UK.

Dobriyal, P.; Qureshi, A.; Badola, R.; Hussain, S.A. 2012. A review of the methods available for estimating soil moisture and its implications for water resource management. Journal of Hydrology 458-459: 110-117.

Donagemma, G.K.; Viana, J.H.M.; Almeida, B.G.; Ruiz, H.A.; Klein, V.A.; Dechen, S. C.F.; Fernandes, R.B.A. 2017. Granulometric analysis = Análise granulométrica. p. 95-116. In: Teixeira, P.C.; Donagemma, G.K.; Fontana, A.; Teixeira, W.G., eds. Manual of methods of soil analysis = Manual de métodos de análise de solo. Embrapa, Brasília, DF, Brazil (in Portuguese).

Evett, S.R.; Tolk, J.A.; Howell, T.A. 2006. Soil profile water content determination. Vadose Zone Journal 5: 894-907.

Fares, A.; Abbas, F.; Maria, D.; Mair, A. 2011. Improved calibration functions of three capacitance probes for the measurement of soil moisture in tropical soils. Sensors 11: 4858-4874.

Feng, G.; Sui, R. 2020. Evaluation and calibration of soil moisture sensors in undisturbed soils. Transactions of the ASABE 63: 265274.

Fontana, A.; Campos, D.V.B. 2017. Organic carbon = Carbono orgânico. p. 360-367. In: Teixeira, P.C.; Donagemma, G.K.; Fontana, A.; Teixeira, W.G., eds. Manual of methods of soil analysis = Manual de métodos de análise de solo. Embrapa, Brasília, DF, Brazil (in Portuguese).

Hillel, D. 1998. Environmental Soil Physics. Academic Press, San Diego, CA, USA. 
Hillel, D. 2013. Advances in irrigation. Academic Press, San Diego, CA, USA.

Huang, Q.; Akinremi, O.O.; Sri Rajan, R.; Bullock, P. 2004. Laboratory and field evaluation of five soil water sensors. Canadian Journal of Soil Science 84: 431-438.

Jacobsen, O.H.; Schjonning, P. 1993. A laboratory calibration of time domain reflectometry for soil water measurement including effects of bulk density and texture. Journal of Hydrology 151: 147-157.

Jin, M.; Zheng, X.; Jiang, T.; Li, X.; Li, X.; Zhao, K. 2017. Evaluation and improvement of SMOS and SMAP soil moisture products for soils with high organic matter over a forested area in northeast China. Remote Sensing 9: 387.

Kaiser, D.R.; Reinert, D.J.; Reichert, J.M.; Minella, J.P.G. 2010. Dielectric constant obtained from TDR and volumetric moisture of soils in southern Brazil. Revista Brasileira de Ciência do Solo 34: 649-658.

Kargas, G.; Kerkides, P. 2008. Water content determination in mineral and organic porous media by ML2 Theta Probe. Irrigation and Drainage 57: 435-449.

Kargas, G.; Ntoulas, N.; Nektarios, P.A. 2013. Soil texture and salinity effects on calibration of TDR300 dielectric moisture sensor. Soil Research 51: 330-340.

Klute, A. 1986. Water retention: laboratory methods. p. 635-662. In: Klute, A., ed. Methods of soil analysis. Part 1. Physical and mineralogical methods. ASA/SSSA, Madison, WI, USA.

Logsdon, S.D. 2009. CS616 calibration: field versus laboratory. Soil Science Society of America Journal 73: 1-6.

Malicki, M.A.; Plagge, R.; Roth, C.H. 1996. Improving the calibration of dielectric TDR soil moisture determination taking into account the solid soil. European Journal of Soil Science 47: 357-366.

Matula, S.; Bát'ková, K.; Legese, W.L. 2016. Laboratory performance of five selected soil moisture sensors applying factory and own calibration equations for two soil media of different bulk density and salinity levels. Sensors 16: 1912.

Mittelbach, H.; Lehner, I.; Seneviratne, S.I. 2012. Comparison of four soil moisture sensor types under field conditions in Switzerland. Journal of Hydrology 430-431: 39-49.

Mortl, A.; Muñoz-Carpena, R.; Kaplan, D.; Li, Y. 2011. Calibration of a combined dielectric probe for soil moisture and porewater salinity measurement in organic and mineral coastal wetland soils. Geoderma 161: 50-62.

Regalado, C.M.; Muñoz Carpena, R.; Socorro, A.R.; Hernández Moreno, J.M. 2003. Time domain reflectometry models as a tool to understand the dielectric response of volcanic soils. Geoderma 117: 313-330.

Rowlandson, T.L.; Berg, A.A.; Bullock, P.R.; Ojo, E.R.T.; McNairn, H.; Wiseman, G.; Cosh, M.H. 2013. Evaluation of several calibration procedures for a portable soil moisture sensor. Journal of Hydrology 498: 335-344.

Santos, H.G.; Jacomine, P.K.T.; Anjos, L.H.C.; Oliveira, V.A.; Lumbreras, J.F.; Coelho, M.R.; Almeida, J.A.; Araujo Filho, J.C.; Oliveira, J.B.; Cunha, T.J.F. 2018. Brazilian Soil Classification System.5ed. Embrapa, Brasília, DF, Brazil.

Sharma, H.; Shukla, M.K.; Bosland, P.W.; Steiner, R. 2017. Soil moisture sensor calibration, actual evapotranspiration, and crop coefficients for drip irrigated greenhouse chile peppers. Agricultural Water Management 179: 81-91.
Shibchurn, A.; Van Geel, P.J.; Kennedy, P.L. 2005. Impact of density on the hydraulic properties of peat and the time domain reflectometry (TDR) moisture calibration curve. Canadian Geotechnical Journal 42: 279-286.

Silva, B.M.; Oliveira, G.C.; Serafim, M.E.; Silva Júnior, J.J; Colombo, A.; Lima, J.M. 2012. Acurácia e calibração de sonda de capacitância em Latossolo Vermelho cultivado com cafeeiro = Accuracy and calibration of capacitance probe in a Rhodic Ferralsol planted with coffee. Pesquisa Agropecuária Brasileira 47: 277-286 (in Portuguese).

Silva, B.P.C.; Silva, M.L.N.; Avalos, F.A.P.; Menezes, M.D.; Curi, N. 2019. Digital soil mapping including additional point sampling in Posses ecosystem services pilot watershed, southeastern Brazil. Scientific Reports 9: 13763.

Silva, C.R.; Andrade Júnior, A.S.A.; Alves Júnior, J.; Souza, A.B.; Melo, F.B.; Coelho Filho, M.A. 2007. Calibration of a capacitance probe in a Paleudult. Scientia Agricola 64: 636-640.

Soil Survey Staff. 2010. Keys to Soil Taxonomy. 11ed. USDA-NRCS, Washington, DC, USA.

Stangl, R.; Buchan, G.D.; Loiskandl, W. 2009. Field use and calibration of a TDR-based probe for monitoring water content in a high-clay landslide soil in Austria. Geoderma 150: 23-31.

Sung, C.T.B. 2012. Aggregate stability of tropical soils in relation to their organic matter constituents and other soil properties. Pertanika Journal of Tropical Agricultural Science 35: 135-148.

Teixeira, W.G.; Schroth, G.; Marques, J.D.; Huwe, B. 2003. Sampling and TDR probe insertion in the determination of the volumetric soil water content. Revista Brasileira de Ciência do Solo 27: 575-582.

Tommaselli, J.T.G.; Bacchi, O.O.S. 2001. Calibration of a TDR equipment to moisture measurement in soils. Pesquisa Agropecuária Brasileira 36: 1145-1154 (in Portuguese, with abstract in English).

Topp, G.C.; Resource, L.; Canada, A. 1980. Electromagnetic determination of soil water content: measurements in coaxial transmission lines. Water Resources Research 16: 574-582.

Topp, G.C. 2003. State of the art of measuring soil water content. Hydrological Processes 17: 2993-2996.

Vaz, C.M.P. 2008. Applicability and limitations of TDR for moisture measurement in Brazilian soils = Aplicabilidade e limitações da TDR para a medida da umidade em solos brasileiros. Embrapa Instrumentação, São Carlos, SP, Brazil. Available at: http://ainfo.cnptia.embrapa.br/digital/bitstream/item/87544/1/ proci-08.00052.PDF [Accessed Apr 20, 2021] (in Portuguese).

Vaz, C.M.P.; Jones, S.; Meding, M.; Tuller, M. 2013. Evaluation of standard calibration functions for eight electromagnetic soil moisture sensors. Vadose Zone Journal 12: 1-16.

Viana, J.H.M.; Teixeira, W.G.; Donagemma, G.K. 2017. Particle density $=$ Densidade de partículas. p. 76-82. In: Teixeira, P.C.; Donagemma, G.K.; Fontana, A.; Teixeira, W.G., eds. Manual of methods of soil analysis = Manual de métodos de análise de solo. Embrapa, Brasília, DF, Brazil (in Portuguese).

Zanetti, S.S.; Cecílio, R.A.; Silva, V.H.; Alves, E.G. 2015. General calibration of TDR to assess the moisture of tropical soils using artificial neural networks. Journal of Hydrology 530: 657-666.

Zhou, Y.; Wang, X.S.; Han, P.F. 2018. Depth-dependent seasonal variation of soil water in a thick vadose zone in the Badain Jaran desert, China. Water 10: 1719. 